ISSN: 0213-2079 - ISSN electrónico: 2386-3889

DOI: http://dx.doi.org/10.14201/shhmo2016381319350

\title{
LOS ABOGADOS DE LA CIUDAD DE VALENCIA DURANTE EL REINADO DE CARLOS I
}

\section{The Attorneys of the City of Valencia under Carlos I Reign}

\author{
Pilar VALOR MONCHO \\ Universidad de Valencia \\ Correo-e: pivamon@gmail.com
}

RESUMEN: Uno de los cargos más desconocidos pero a la vez más influyentes del organigrama político de la ciudad de Valencia fue el de abogado de la Ciudad, de ahí el interés de la Corona por controlarlo. En este trabajo acometemos, a partir de la documentación del Archivo Municipal de Valencia, las características de este oficio y la relación de quienes lo desempeñaron durante el reinado de Carlos I, nombrados siempre por el Consell Secret y ratificados por el Consell General. La excesiva carga laboral de muchos de ellos, dejaba en ocasiones desprotegida jurídicamente a la capital, habilitándose durante este periodo los cargos de abogados extraordinarios y de coadjutores, como paso previo - cuando quedara alguna vacante-, para ejercer como abogados de la Ciudad.

Palabras claves: Carlos I; Valencia; gobierno; abogados de la Ciudad.

ABSTRACT: One of de most unknown positions but at the same time the most influential of the political structure of Valencia City was the city attorney. Therefore it did exist an specific interest from de monarchy to control this position. In our report we study the features of this type of position and we present a list of the position holders who were appointed from the Consell Secret and ratified from the Consell General during Carlos I reign. All this information is based on documentation from Archivo Municipal de Valencia. Occasionally the City was legally unprotected due to the overload amount of work experienced from many of the attorneys. In such cases, the

(C) Ediciones Universidad de Salamanca / ®@ Stud. his., H. ${ }^{a}$ mod., 38, n. 1 (2016), pp. 319-350 
City was provided with extra number of attorneys and assistants. For the assistants this was the first step into the possibility to act as a city attorney if any position became available.

Key words: Carlos I; Valencia; Government; City of Attorney.

A comienzos del siglo xvi el gobierno de Valencia estaba en manos de una serie de oficiales que desempeñaban diferentes cometidos: seis jurados, el racional, el síndico, el escribano y cuatro abogados de la Ciudad, quienes conjuntamente configuraban el ejecutivo municipal, conocido como el Consell Secret. Este artículo pretende profundizar en el conocimiento de los diferentes juristas que ejercieron como abogados de la Ciudad en la capital del reino a lo largo del reinado de Carlos I, su acceso y su perpetuación en el cargo, a partir fundamentalmente de la documentación extraída del Archivo Municipal de Valencia. Tras una escueta introducción sobre el cargo de abogado de la Ciudad, hemos dividido el trabajo en tres apartados. En el primero profundizaremos en la polémica generada, tras la muerte del rey Católico, por el cese de los abogados de la Ciudad nombrados por este y la designación de otros más afines a los intereses del Municipio. En el segundo, describiremos brevemente la actitud de los diferentes abogados de la Ciudad que se sucedieron durante el periodo agermanado. Finalmente, en el tercer apartado, detallaremos las diferentes medidas adoptadas por los dirigentes capitalinos para subsanar la falta de asesoramiento legal ante la frecuente inhibición de los letrados.

Desconocemos el momento en que se instituyó este oficio bajo el patrocinio de los jurados. A lo largo de los años centrales del siglo xIV el número de juristas que asesoraban al Municipio pasó de dos a cuatro, según determinación del Consell General. Debían ser valencianos, licenciados en Derecho y remunerados con 1.000 sueldos, reservándose el mismo Consell la facultad de cesarlos ${ }^{1}$. Las plazas eran cubiertas de manera poco clara al menos hasta que en 1389 se acordó realizarse en el Consell General de la vigilia de San Miguel, -inmediatamente después de la elección del almotacén-, por el método de redolinos en que participarían los seis abogados con más reputación en la urbe. El cargo sería anual, no pudiendo repetir hasta un trienio después ${ }^{2}$. La realidad, sin embargo, era muy distinta, por cuanto la designación la realizaban los jurados, entre las personas más idóneas, con el refrendo del Consell General. Además la permanencia, al contrario de lo

1. Gual Camarena, M.: «Los abogados de la ciudad de Valencia en el siglo xiv. Notas y documentos», VIII Congreso de Historia de la Corona de Aragón, vol. II. Valencia, 1970, pp. 229-231. Graullera Sanz, V.: Los primeros juristas valencianos. Valencia en la Baja Edad Media. s. XIII Y XIV. Valencia, 2000. pp. 92-100.

2. Vidal Beltrán, E.: Valencia en la época de Juan I. Valencia, 1974, pp. 144, 157.

(C) Ediciones Universidad de Salamanca / ®@ Stud. his., H. ${ }^{a}$ mod., 38, n. 1 (2016), pp. 319-350 
establecido, era vitalicia, pues los únicos cambios que se registraron fueron por óbito o cese $e^{3}$. Ante estas circunstancias, en 1396 se planteó la posibilidad de reducir su duración -por su falta de efectividad y competencia- aunque no prosperó ${ }^{4}$.

Por tanto, ya desde finales del siglo xiv, los jurados de Valencia contaban con el asesoramiento legal de cuatro abogados, que gozaron de una gran importancia por su mayor permanencia en el cargo frente al carácter anual o trienal de los restantes oficios municipales.

Su función era asesorar jurídicamente al Consell Secret y al Consell General, participando diariamente de forma activa en las funciones de gobierno y administración de la capital, con la elaboración de informes verbales para los jurados, con quienes departían diariamente, o la redacción de ordenanzas municipales, instrucciones para las embajadas que de manera continuada enviaba la Ciudad a la Corte o memoriales para las Cortes Generales. Asimismo, examinaban la legislación emitida por la Corona, bajo la forma de privilegios, provisiones o sentencias, comprobando que no transgredieran las libertades forales concedidas con anterioridad ${ }^{5}$. También, obviamente, les atañía la defensa del Municipio en los pleitos que mantenía con otras instituciones o particulares, incluso se encargaban de causas que no solo afectaban a la ciudad sino al reino.

Por tanto, gran parte de la tarea de los abogados residía en la interpretaciónaplicación de la legislación foral sin olvidar sus atribuciones políticas como miembros del Consell Secret.

Estas características hacían que los monarcas, -como ocurrió en Orihuela-, quisieran controlar el nombramiento de los abogados capitalinos ${ }^{6}$. Durante el reinado de Carlos I, fueron siempre provistos por el Consell Secret y refrendados por el Consell General, después de la injerencia de Fernando el Católico. De hecho, en 1590 los dirigentes oriolanos pidieron a la Corona la devolución de la facultad de nombrar al abogado de la Ciudad, tal como se practicaba en los restantes municipios valencianos ${ }^{7}$.

3. Narbona Vizcaíno, R.: «Los Rabassa, una familia patricia de Valencia medieval», Anales de la Universidad de Alicante. Historia medieval, 7, 1988-1989, p. 124.

4. Graullera Sanz, op. cit., pp. 92-100.

5. Narbona Vizcaíno, op. cit., p. 125.

6. Bernabé Gil, D.: «Los juristas en la burocracia municipal. Asesores y abogados ordinarios de la ciudad de Orihuela en el siglo XVII", Homenatge al doctor Sebastià Garcia Martínez, vol. II. Valencia, 1988, pp. 133-147.

7. Idem, pp. 137-138.

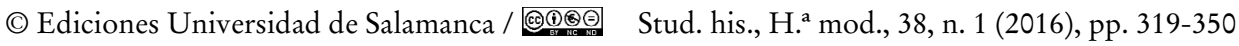




\section{Pólemica en los inicios del Reinado Carlos I}

La muerte de Fernando el Católico y la ausencia de un heredero con experiencia, impulsó a los dirigentes municipales valencianos a adoptar medidas tendentes a recuperar parte de su autonomía frente al poder regio, revisando el sistema de elección de jurados, racional y abogados de la Ciudad. Respecto a estos últimos, el Consell Secret del 19 de junio de 1516, en virtud del poder concedido por el Consell General del 30 junio $1435^{8}$, cesó a los entonces abogados, -micer Baltasar Gallach ${ }^{9}$, micer Francisco d'Artés ${ }^{10}$, micer Ausias Bosch ${ }^{11}$ y micer Francisco Ros ${ }^{12}$-, sustituyéndolos por micer Damián Andrés, hermano del jurat en cap Miguel Andrés, y micer Jerónimo d'Assio, hermano del síndico. Estos dos últimos fueron requeridos inmediatamente para jurar el correcto ejercicio de su cargo, aconsejando legalmente a los jurados y manteniendo la confidencialidad en los asuntos municipales.

El cese a los afectados les fue comunicado personalmente. Micer Ausias Bosch y micer Gallach disintieron de la decisión del Consell Secret, alegando su gestión como abogados de la Ciudad y la imposibilidad legal de los jurados para rescindir cargos designados por los monarcas. Diferente fue la posición de micer Francisco

8. Un poder que ratificaba la facultad de los jurados, el racional y el síndico sobre los cargos municipales para nombrarlos, revocarlos, establecer sus emolumentos y todo aquello que estimaran oportuno para el beneficio de la ciudad. Arhivo Municipal de Valencia [en adelante AMV]. MC, A-31, fol. 15.

9. Micer Baltasar Gallach fue el primer regente de la Audiencia de Valencia desde 1506 hasta su fallecimiento, en octubre 1518, cubriéndose la plaza por micer Eximeno Pérez de Figuerola, hasta entonces regente del Consejo de Aragón. CANET APARISI, T.: La Magistratura Valenciana (s. XVI-XVII).Valencia, 1990, p. 32.

10. Nombrado abogado de la Ciudad el 27 de octubre de 1502 por el fallecimiento de micer Miguel Albert. AMV. MC, A-51, fol. 43v. Catedrático de Prima de Leyes durante el curso 15101511, pero fue cesado en noviembre de 1511. Felipo OrTS, A.: La Universidad de Valencia en el siglo XVI (1499-1611). Valencia, 1993, p.177. En enero de 1490 fue nombrado abogado del estamento militar, labor en la que se mantuvo hasta al menos 1510. LORITE MARTínez, I.: Las deliberaciones del Estamento militar valenciano (1488-1510). Tesis de licenciatura inédita. Valencia, 1999, pp. 19-20.

11. Ocupó una de las cátedras de Derecho Civil desde 1500 hasta el curso 1506-1507, en el que fue sustituido por Jerónimo d'Assio. FELIPO ORTS, op. cit., p. 177.

12. Hijo de micer Martín Eximeno Ros de quien heredó el cargo de abogado de la Ciudad en 1514. El 4 de enero de 1509 fue nombrado rector de la Universidad de Valencia, siendo sustituido el 4 de mayo de 1510 por Jaime Conill. Entre 1500-1503 ocupó las cátedras de Poesía y Oratoria y posteriormente se graduó doctor en ambos Derechos. FELIPO ORTS, op. cit., p. 29. Fue nombrado regente de la Real Cancillería de Mallorca por Fernando II, el 14 de octubre de 1515, con la misión inicial de investigar la veracidad de una serie de denuncias lanzadas contra su predecesor. Se mantuvo hasta 1518, en que fue reemplazado por Jaime Roque. JUAN VIDAL, J.: El sistema de gobierno en el reino de Mallorca (siglos XV-XVII). Mallorca, 1996, pp. 201-202.

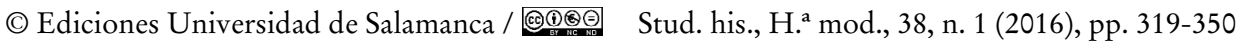


d'Artés, quien aceptó la revocación con gran beneplácito ${ }^{13}$. El otro jurista afectado por el cese, micer Francisco Ros, no recibió notificación por estar ejerciendo como regente de la Real Cancillería en el reino de Mallorca.

Pero la reacción de los implicados no quedó reducida a una simple protesta en el ámbito municipal, sino que elevaron quejas al rey, quien adoptó una postura favorable a los juristas y contraria a la decisión municipal.

El pretexto utilizado para destituirlos fue que simultaneaban varios cargos, incurriendo en contrafuero. En la escalada de defensa de los Fueros y Privilegios y reducción del intervencionismo regio iniciada tras el óbito del Católico, la situación de micer Baltasar Gallach como asesor del gobernador y regente de la Real Cancillería de Valencia, de micer Ausias Bosch como asesor del Baile General, de micer Francisco Ros como regente de la Real Cancillería de Mallorca y de micer Francisco d'Artés como abogado del estamento militar, constituyó el argumento perfecto para desprenderse de unos abogados nombrados por Fernando II, -que presumiblemente anteponían los intereses reales a los de la Ciudad-, y reemplazarlos por otros más afines a sus ideas, de preferente obediencia municipal.

Cinco meses más tarde, el 10 octubre de 1516, desde Bruselas, el monarca mostraba su descontento por la actitud insumisa de la Ciudad a propósito de la elección de los jurados y la revocación y nuevo nombramiento del racional y abogados. Es más, instó a que estos últimos fueran destituidos, advirtiendo que en el caso de que se quisiera deponer a alguna persona de su puesto se le consultara para determinar lo más oportuno ${ }^{14}$. Al mismo tiempo, envió a cada jurado una carta de acreditación en favor del Gobernador para que les explicara que su deseo era que los cesados recuperaran sus puestos en el término de dos días. Pero todo fue inútil. Los magistrados municipales no transigieron, argumentando que los ceses habían sido efectuados por el Consell General y que ellos no tenían poder para modificar sus decisiones. Así las cosas, en el Consell General, del 7 de noviembre de 1516, se decidió informar al rey por vía de embajada que las rescisiones y nuevos nombramientos de abogados y racional estaban legitimados por Fueros y Privilegios y acallar así las falsas informaciones que sobre ese tema se le estaban dando. Además, se notificó al Gobernador la intención de la Ciudad de acudir a la Corte para que entretanto se abstuviese de adoptar medidas sobre los asuntos que le consultarían.

Una semana después, el Gobernador, don Luis de Cabanyelles, envió a los jurados y al Consell General una carta de acreditación del monarca, fechada también el 10 de octubre, que le facultaba para dar las explicaciones necesarias

13. AMV. $M C$., A-57, fols. 41-42v.

14. AMV. MC., A-57, fols. $132 \mathrm{v}-134$.

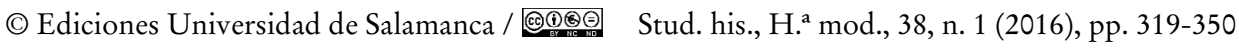


en defensa de las regalías y preeminencias de la Corona. Consecuentemente, cuatro días después, se convocó Consell General y, tras requerirse la presencia del Gobernador, este presentó un escrito en el que insistía en la decepción del monarca por los ceses de los abogados nombrados por su abuelo, en uso de su potestad regia, porque lo consideraba un ataque a sus poderes, amén de la inexistencia de fueros que legitimasen la actuación de la Ciudad, solicitando un cambio de actitud municipal bajo la amenaza de la aplicación de medidas drásticas. Tras abandonar la Sala el Gobernador, se decidió ratificar los acuerdos adoptados en la sesión del 7 de noviembre y razonar al rey su injustificada postura ante los ceses municipales, primero por medio de correo tramitado por el Consell General y, si este recurso no diera resultado, con la remisión de una embajada, que empezó a perfilarse ese mismo día. Insistiéndole a don Luis de Cabanyelles que no ejecutase ninguna provisión respecto a los ceses, haciéndole memoria, como prueba de la fidelidad de la Ciudad, los muchos servicios que de esta había recibido cuando le respaldó y colaboró con él en los altercados originados a la muerte de Fernando II ${ }^{15}$.

La premura en los preparativos de la embajada, se utilizó como elemento de presión en la carta de consulta remitida a Carlos I el 4 de diciembre en la que se le exponía por parte de los ediles municipales su deseo de servirle como lo habían hecho con sus predecesores, quienes por los muchos favores que recibieron de Valencia la privilegiaron dándole poder para autogobernarse:

donant lo regiment y administració de la universitat y república als jurats d'aquella $a b$ que administrassen ab consell dels consellers que tendrien y ells se elegirien volent ab los Privilegis expressament que no fossen tenguts los dits jurats dar rahó de la administració als dits Reys y que de tot lo que seria per aquells administrat se tendrien per contents y axí mateix que no haguessen de revelar los secrets del dit Consell als dits Reys ni algú altre ${ }^{16}$.

En virtud de este arbitrio, los antiguos jurados, ante la necesidad de que alguien controlara las finanzas municipales, eligieron a un racional y, más tarde, con el fin de tener un mayor asesoramiento legal, nombraron cuatro abogados de la Ciudad. Todas estas decisiones fueron confirmadas por los reyes de Aragón y, por lo tanto, era legal la potestad de los jurados y del Consell General para nombrar y cesar a los diferentes cargos municipales. Se buscaba pues que el monarca aceptara, sin menoscabo de sus preeminencias, las revocaciones del regente del oficio de racional y de los abogados, hechas por su mala gestión, e hiciera caso omiso a las personas que en torno a él le instigaban a mantenerlos en el cargo, aunque ello conllevase

15. AMV. MC, A-57, fols. 100-101v, 112, 197.

16. AMV. $M C, \mathrm{~A}-57$, fol. 227.

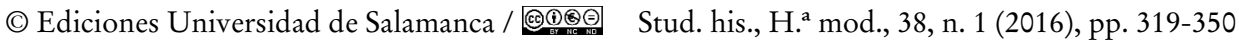


una reducción de los derechos y Privilegios de la ciudad. El dedo acusador de los jurados señalaba a los abogados cesados quienes, primero directamente y luego a través del Gobernador, habían mantenido contactos con Carlos I para recuperar su puesto. Además, los jurados le advirtieron que, en caso de denegarles esta petición, se verían obligados a enviar una embajada, lo cual significaría un gran desembolso económico para una ciudad que no atravesaba una buena situación, a causa de los numerosos préstamos concedidos a su abuelo.

La respuesta regia, fechada en Bruselas el 22 de enero de 1517, tuvo varios destinatarios: el ejecutivo valenciano, el Gobernador y los dos abogados de la Ciudad. En la misiva dirigida a los jurados y al racional, el monarca rechazó las razones aportadas para legitimar sus actuaciones y, por lo tanto, ordenó que inmediatamente restituyeran a los abogados, amenazándoles con la aplicación de duras penas y no olvidar esta inobediencia. Además, les aconsejó que se abstuvieran de enviar embajada alguna ya que esta sería «a costa y danyo de vosaltres» ${ }^{17}$. A don Luis de Cabanyelles le encargó que hiciera efectiva sin dilación la rehabilitación de los juristas cesados, bajo pena de 10.000 florines. Estos habían denunciado ante el rey que su destitución era contraria a las prerrogativas reales, pues conscientes de esta ilegalidad, los dirigentes municipales, el mismo día de los cese, -el 23 de junio de 1516-, intentaron legitimar su acción con la aprobación en Consell General de una nueva norma por la que nadie que tuviera molinos en el término de la ciudad de Valencia pudiera ostentar oficio en ella ${ }^{18}$. Había otros dos destinatarios de la reacción real, micer Damián Andrés y micer Jerónimo d'Assio, a los que se les pidió que renunciaran a su cargo de abogados de la Ciudad. Esta vez la solicitud regia fue aceptada.

Ante estas dimisiones y las amenazas reales, los jurados replantearon el tema en el Consell General del día 13 de febrero de 1517, donde, tras conocerse la reacción regia, se abrió el turno de intervenciones, siendo la opción más apoyada, -con setenta votos-, la defendida por el consejero mosén Guillermo Ramón de Pertusa, quien presentó varias medidas: explicar al monarca la situación a través de una embajada; enviar otra al Gobernador para requerirle que no ejecutara las penas impuestas por Carlos I; no aceptar las renuncias de los dos abogados; y derogar la potestad concedida al Consell Secret el 30 de junio de 1435 de nombrar, elegir y revocar a algunos oficiales de la Ciudad ${ }^{19}$.

17. AMV. $M C$, A-57, fol. 229.

18. Micer Gallach y micer Ros eran propietarios de molinos harineros. AMV. MC, A-57, fol. 55 .

19. AMV. Qüerns de Provisions (PQ), B-13.

(C) Ediciones Universidad de Salamanca / ®@ Stud. his., H. ${ }^{a}$ mod., 38, n. 1 (2016), pp. 319-350 
La reincorporación a su oficio de micer Damián Andrés y micer Jerónimo Assio, aprobada por la mayoría, no se produjo. El abandono de sus funciones -no mencionado de forma explícita en ningún documento de renuncia-, queda patente con su ausencia, a partir de esta fecha, en casi todas las convocatorias del Consell General. Asimismo, en dos de sus sesiones se adoptaron medidas para recompensar a los consejeros juristas que asesoraban a la Ciudad, justificándose por la falta de abogados ${ }^{20}$.

En el Consell General del 9 de marzo de 1517 se aprobaron las instrucciones para los embajadores en cuya elaboración participaron los jurados, el racional, el síndico, los cuatro abogados consejeros, micer Francisco Penaroia y los destituidos micer Damián Andrés y micer Jerónimo d'Assio ${ }^{21}$. Unas instrucciones, -desarrolladas en diecisiete capítulos-, en las que lo primero que harían los emisarios sería recordarle su deber de acudir al reino de Valencia no solo para cumplir con la obligación de jurar los Fueros y Privilegios de la ciudad y del Reino, sino para evitar males mayores. A continuación, le expondrían el resto de las demandas municipales, centradas en cuatro aspectos: la defensa de los derechos de la Ciudad en la provisión de sus cargos; la correcta administración de justicia; los asuntos económicos y la transparencia en la gestión de los diferentes cargos. Se aprecia, por tanto, que el ámbito de discusión que hasta ahora mantenía la Ciudad con el rey se amplió con otras reivindicaciones de índole económica y judicial. Con esta estrategia, los dirigentes capitalinos demostraron que, lejos de sentirse coaccionados por la postura intransigente y amenazadora del rey, se sintieron lo suficientemente fuertes para defender no solo su potestad sobre los cargos municipales, sino también para denunciar otros excesos de poder por parte del monarca y sus delegados. Respecto a la política municipal, se le pediría a Carlos I que respetara la forma de elección de los jurados restaurada en 1516, la libertad del Consell Secret y del Consell General para poder elegir a los diferentes oficios municipales, -en

20. En la primera de estas sesiones, celebrada el 30 de mayo, se dispuso que se entregaran a los consejeros juristas, micer Josué de Sent Feliu, micer Jaime Roca, micer Juan Ferrando y micer Francisco Esteve, 10 ducados y un par de antorchas, por aconsejar a la Ciudad. Dos meses más tarde, el Municipio continuaba sin abogados por lo que de nuevo, el 14 de agosto, se aprobó que se remunerara a los nuevos consejeros juristas, micer Pedro Navarro, micer Luis Alcanyiç, micer Bartolomé Monfort y micer Baltasar Morell, con el salario que percibían los abogados de la Ciudad «com al present no haia advocats de aquella per aconsellar-la y és rahó que aquells sien pagats puix sostenen los treballs com advocats». El clavario común les entregó 8 libras, antorchas y cajas como primer pago. AMV. $M C, \mathrm{~A}-57$, fols. $419 \mathrm{v}, 517,547 \mathrm{v}$.

21. Los nombres de estos dos últimos no aparecen en el listado de asistentes de este Consell General pero sí en el Qüerns de Provisións donde además se observa que en esta sesión triunfó la opinión que micer Damián Andrés dio a todas las propuestas de los jurados, con 52 votos. AMV. $P Q, \mathrm{~B}-13$.

(C) Ediciones Universidad de Salamanca / ®@ Stud. his., H. ${ }^{a}$ mod., 38, n. 1 (2016), pp. 319-350 
virtud de lo cual le solicitarían la cancelación de todas sus disposiciones respecto a los ceses y nuevos nombramientos del racional y abogados-, y la inmunidad de los jurados y consejeros ante la actuación de los inquisidores que, por comisión regia, estaban recabando información contra ellos ${ }^{22}$.

Del 12 al 17 de marzo de 1517, el síndico presentó varias notificaciones extrajudiciales, entre ellas a los cuatro abogados cesados para que sufragaran los gastos de la embajada, -unos 1.000 ducados-, por estar implicados en algunos de los contrafueros que se intentarían reparar, culpándoles de maquinar contra la Ciudad dando siniestras informaciones al monarca con el fin de recuperar su puesto $^{23}$. Acusación que no fue aceptada por ninguno de los juristas. Micer Baltasar Gallach apeló al rey como el único que podía verificar esta denuncia y obligar al pago de la embajada. Micer Ausias Bosch recordó que Carlos I ya había advertido que si se le enviaba alguna embajada los gastos correrían a cuenta de la Ciudad.

Los legados de la capital -mosén Guillermo Ramón de Pertusà y micer Francisco Penaroia-, partieron la tarde del 19 de marzo. Seis meses después, el 22 de agosto de 1517, ante el fracaso de las negociaciones, por la lentitud y las trabas burocráticas, se les ordenó regresar a Valencia en el plazo de quince días, dejando en la Corte las instrucciones para que se continuaran analizando.

Ya en tierras españolas, a finales de marzo de 1518, Carlos I envió un ultimátum a los jurados y al racional para que restituyeran a los abogados cesados en la pasada juradería, bajo la amenaza de duras penas ${ }^{24}$. El 25 de marzo, el Consell Secret, considerando además que la Ciudad restaba sin letrados desde la dimisión de micer Damián Andrés y micer Jerónimo d'Assio, restableció a micer Baltasar Gallach, micer Francisco d'Artés, micer Ausias Bosch y micer Francisco Ros, con todos los salarios, preeminencias y prerrogativas de que gozaban anteriormente. Esta claudicación, tras una larga lucha por mantener el control sobre estos cargos, pudo deberse a las fuertes sanciones con que se amenazó al gobierno municipal, o quizá se buscó con ella complacer al monarca para evitar su intervención en

22. Esta última demanda se aprobó en el Consell General del 16 de mayo de 1517, a partir de la denuncia que presentó mosén Juan Alegre tras el interrogatorio al que le sometieron los inquisidores comisionados. Visto lo cual, se decidió enviarles una embajada para que mostraran los poderes que legitimaban su actividad y para que interrumpieran su investigación hasta que fuera consultado el monarca. A este, además de denunciarle la acción contraforal de los inquisidores -por cuanto, a partir del privilegio CLII de Jaime II, ni civil ni criminalmente los jurados y consejeros podían ser imputados ni se les podía pedir cuentas-, se le recomendaría que recabase información sobre la actuación de sus oficiales. AMV. $M C, \mathrm{~A}-57$, fol. 308v.

23. AMV. $M C, \mathrm{~A}-57$, fol. 286.

24. Dada en Valladolid el 22 de febrero de 1518. AMV. Cartas reales, h3 - 3, fols. 27v - 28.

(C) Ediciones Universidad de Salamanca / ®@ Stud. his., H. ${ }^{a}$ mod., 38, n. 1 (2016), pp. 319-350 
la provisión de la nueva juradería, a celebrar a finales del mes de mayo, o para acelerar su visita a Valencia.

Rehabilitación que no estuvo exenta de polémica, pues no fue aceptada ni por el ex-consejero mosén Juan Alegre ni por dos consejeros mosén Francisco Juan y mosén Francisco Juan de Pertusa puesto que consideraban nula la decisión del Consell Secret al haber sido revocada su facultad de nombrar a los oficios municipales, en la deliberación del 13 de febrero de 1517. Ante el temor a que esta reclamación ganara más adeptos, los abogados de la Ciudad informaron al rey, quien envió a estos opositores dos cartas donde se les pedía, veladamente, que depusieran su postura. En la primera, fechada el 16 de abril en Aranda del Duero, Carlos I les exigió no perturbar la reciente restitución de los juristas ${ }^{25}$. En la segunda, del 15 de mayo, les ordenó, bajo pena de 10.000 florines, acudir con urgencia a la Corte donde se les comunicaría la causa de su requerimiento ${ }^{26}$.

A pesar de la amenaza regia, el 22 de mayo de 1518, uno de estos consejeros, mosén Francisco Juan, solicitó a los jurados que incluyeran entre las provisiones que se plantearían en el Consell General de ese día la reposición de los letrados, petición rechazada por falta de tiempo, aunque se dejó abierta la posibilidad de plantearlo en futuras reuniones. De este modo, los jurados salientes, lejos de resolver el asunto, lo trasladaban a los siguientes.

Así, en la primera reunión del Consell General de la nueva juradería, el día 23 de junio, tres miembros del estamento militar, mosén Guillermo Ramón de Pertusa, mosén Francisco Penaroia y mosén Pedro Joan, procuradores de los tres ex-consejeros, se personaron en la Casa de la Ciudad para lograr que el asunto de los abogados de la Ciudad fuera uno de los temas a tratar ${ }^{27}$. Los jurados se negaron porque no se podían debatir en Consell General asuntos que previamente

25. «A nos es hecha relación que haviendo restituido en sus oficios a los advogados antigos dessa ciudat en virtud de provisiones y letras nuestras, vos, con algunas otras personas dessa dicha ciudat, lo que creer no podemos, procuréis de no perturbar e impedir, por vías escandalosas, de que si ansí es nos seríamos mucho deservido. Que por ende vos encargamos y mandamos que procureys de poneros en tal cosa que allende que no saldríades con ella nos daríades causa de indignación y mandaríamos fazer la provisión sobre ello que por la obra podría desconocer el sentimiento que dellos». AMV. MC, A-58, fol. 36.

26. «so pena de la fidelidad de que nos soys tenido y de 10.000 florines de oro, que dentro de hun día natural después que esta carta vos será presentada os partays desta ciudat de Valencia y drecha vía vengáys personalmente a esta ciudat y parescáys ante nos o nuestro real consejo para que se os notifique la causa de vuestra venida, sin poner en ello scusa ni dilación alguna porque os certificamos que en caso contrario, lo que no creemos, vos mandaremos irremisiblemente ejecutar las dichas penas como inobediencia de nuestros mandatos». AMV. MC, A-58, fols. 36v-37.

27. Dos de estos representantes, mosén Guillermo Ramón de Pertusa y micer Francisco Penaroia, fueron los integrantes de la embajada enviada el 19 de marzo de 1517.

(C) Ediciones Universidad de Salamanca / ®@ Stud. his., H. ${ }^{a}$ mod., 38, n. 1 (2016), pp. 319-350 
no hubieran sido propuestos por el Consell Secret, según un establecimiento de 1380. No obstante, se les pidió la escritura que pretendían presentar; pero se negaron, pues su objetivo era transmitirla a los consejeros sin pasar primero por el tamiz de los jurados. Ante su persistente negativa, se solicitó al justicia civil que los expulsara, bajo pena de 100 florines a cada uno. Antes de marcharse, estos entregaron la escritura al síndico para que la leyera en el Consell General. En ella, los tres antiguos consejeros denunciaban la actitud prepotente de los dirigentes capitalinos quienes, a pesar de haber sido desprovistos del poder atribuido en 1435, restituyeron a los abogados de la Ciudad sin consultar a los consejeros. Algunos de ellos, como mosén Francisco Joan y Francisco Juan de Pertusa, intentaron que esta decisión fuera analizada en la primera reunión del Consell General que se celebrara, pero los jurados y abogados procuraron eludir esta celebración por temor a la reacción de los consejeros hasta que finalmente, por obligación legal, convocaron la última sesión de la juradería en la cual consiguieron soslayar el asunto. Además, señalaron a los abogados de la Ciudad como los promotores de las dos amenazantes cartas reales que habían recibido. Por ello, los tres ex-consejeros solicitaban que todos los gastos que su viaje a la Corte ocasionara les fueran costeados y poder hacer uso de la carta de indemnidad, redactada el 2 de marzo de $1517^{28}$, sugiriendo que en esa deliberación no intervinieran los abogados de la Ciudad por ser parte implicada ${ }^{29}$.

Conocido el contenido del documento, los jurados Guillermo March, mosén Gaspar Felipe de Cruilles, Francisco Gil y Bartolomé Vernegal, aconsejados por los letrados, se negaron a que se leyera en el Consell General y aprobaron añadir a renglón seguido su respuesta, a pesar de la negativa de mosén Miguel Ángel Bou y Miguel Berenguer, quienes pretendían reflexionar más sobre el tema. En su réplica los dirigentes municipales les advirtieron sobre el incorrecto proceder en su protesta, puesto que antes de provocar este escándalo podían haber preguntado a los jurados salientes la razón del restablecimiento de los abogados de la Ciudad y si estos no les hubieran querido dar explicaciones, siguiendo la vía formal, tendrían que haber presentado una propuesta a los jurados, quienes la hubieran incluido en las cuestiones del Consell General si la hubieran estimado oportuna. Desmintieron la participación de los abogados de la Ciudad en las dos misivas regias que habían recibido, pues estas, debido a su escasa concreción, las pudo remitir el rey motu propio. Les denegaron el uso de la carta de indemnidad ya que solo podía ser utilizada por aquellos que ciertamente defendían las leyes y costumbres de la

28. AMV. $M C, \mathrm{~A}-57$, fols. $254 \mathrm{v}-255$.

29. AMV. $M C, \mathrm{~A}-58$, fols. $33-38 \mathrm{v}$.

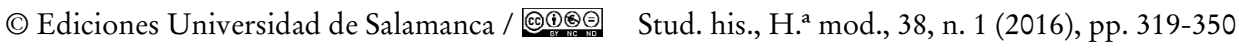


ciudad por vías legales, contando con la aprobación del Consell General, y hasta ese momento se desconocía realmente la causa del requerimiento real.

Esta falta de unanimidad entre los jurados provocó que el síndico replanteara el asunto una semana más tarde, pidiendo que se evitara el viaje de los tres caballeros a la Corte, respecto a lo cual, mosén Gaspar Felipe de Cruilles defendió ante al resto de los jurados la posibilidad de escribir al monarca para informarle de lo acontecido los últimos días, preguntarle las razones del llamamiento y solicitarle la revocación de dichas órdenes. Dos de los jurados, Francisco Gil y Bartolomé Vernegal, respaldaron esta propuesta, mientras que mosén Miguel Ángel Bou y Miguel Berenguer, manteniendo su línea habitual, se negaron; aunque dejaron abierta la posibilidad de modificar su postura si algunos juristas, a los que habían pedido consejo, les indicaban lo contrario. De esta consulta excluyeron a los abogados de la Ciudad por considerarlos parte del problema. El último jurado en contestar fue Guillermo March, quien admitió la consulta al monarca siempre y cuando se cumpliera todo lo propuesto, mostrándose partidario de que este asunto se tratara en Consell General. Igualmente, Miguel Berenguer aceptó que se preguntara a los consejeros, pero solo sobre el disfrute o no de la carta de indemnidad por parte de los tres caballeros ${ }^{30}$.

A partir de este punto perdemos el rastro al asunto en la documentación municipal manejada. No obstante, la muerte de micer Baltasar Gallach, el 16 de octubre de 1518, y la elección de un nuevo abogado de la Ciudad, sin esperar el nombramiento regio, puso de relieve el carácter eventual de la concesión municipal. Los diferentes cargos que el finado ocupaba se distribuyeron entre los otros abogados de la Ciudad. Así, micer Francisco d'Artés y micer Francisco Ros le sucedieron en el cargo de abogado de Murs $i$ Valls y en el de abogado de las baronías de la Pobla de Vallbona, Paterna y Benaguasil, respectivamente ${ }^{31}$. El 18 de octubre, reunido en la sala dorada, el Consell Secret eligió como nuevo asesor jurídico a micer Dimas de Aguilar. Pero la protesta de dos de los jurados, mosén Gaspar Felipe de Cruilles y Guillermo March, del racional y del síndico, por cuanto consideraban que no tenían poder para hacer este nombramiento, provocó la convocatoria para el día siguiente del Consell General, donde se confirmó la elección.

Por su parte, Carlos I, al conocer la noticia de este óbito, ordenó a los jurados y al racional que no proveyeran nada respecto al cargo de abogado de la Ciudad y de Murs $i$ Valls, pero la advertencia llegó tarde ${ }^{32}$. Esta vez el Consell General no cedió a la petición regia y mantuvo en el cargo a micer Dimas de Aguilar,

30. AMV. $M C, \mathrm{~A}-58$, fols. $57 \mathrm{v}-63 \mathrm{v}$.

31. AMV. $M C, \mathrm{~A}-58$, fol. $134 \mathrm{v}-36$.

32. AMV. $M C, \mathrm{~A}-58$, fol. 149.

(C) Ediciones Universidad de Salamanca / ®@ Stud. his., H. ${ }^{a}$ mod., 38, n. 1 (2016), pp. 319-350 
comunicándoselo al monarca y a dos de sus consejeros, micer Antonio Agustín y micer Jimeno Pérez de Figuerola, para que intercedieran en favor de la decisión de la Ciudad ${ }^{33}$.

\section{LOS ABOGADOS DE LA CIUDAD DURANTE EL PERIODO AGERMANADO}

El 23 de junio de 1520, dentro de la aspiración agermanada de hacerse con el control de los principales cargo municipales, una de las primeras medidas que adoptaron fue el cese de dos de los abogados de la Ciudad, micer Francisco Ros y micer Ausias Bosch, manteniéndose a los otros dos, micer Francisco d'Artés y micer Dimas Aguilar. El objetivo de los consejeros era poder nombrar a juristas más afines a su causa, por lo que no dudaron en buscar cualquier pretexto para apartarlos de su cargo. De este modo, como micer Francisco Ros sí que cumplía con su misión de asesorar, el argumento que se esgrimió fue que era propietario de molinos, aunque la verdadera razón debió ser su postura contraria a la Germanía. Por contra, como la enfermedad impedía a micer Ausias Bosch ejercer su cargo, simplemente se recurrió al pretexto de que no servía a la Ciudad. Los otros dos abogados, micer Francisco d'Artés -cuyas opiniones en las deliberaciones del Consell eran muchas veces respaldadas por la mayoría de los asistentes- y micer Dimas Aguilar, conservaron su cargo ${ }^{34}$. De este último no se advierte nada en esta resolución. Pero su presencia en la reunión que aprobó los capítulos de los tundidores confirma su continuidad ${ }^{35}$.

Para cubrir las vacantes se recurrió al sistema de escrutinio a partir de una lista de seis candidatos elaborada por los jurados: micer Bartolomé Rodríguez, micer Damián Andrés, micer Francisco Esteve, estos tres consejeros juristas; y micer Francisco de Sent Feliu, micer Bartolomé Camós ${ }^{36}$ y micer Bartolomé Monfort, abogado del pueblo. Estos dos últimos fueron los que lograron un mayor número

33. AMV. Lletres misives, g3 - 41. fol. 30.

34. Cuando se planteó este asunto se adoptaron dos posturas. Una más conciliadora, defendida por el abogado micer Francisco d'Artés, y apoyada con 20 votos, quien pretendía que un verguero y un escribano fueran a casa de micer Francisco Ros y de micer Ausias Bosch para requerirles que acudieran a la ciudad a ocupar su cargo, en el plazo de ocho días. En torno a esta idea estuvieron las propuestas de Baltasar Miguel y Jaime Gisbert. Pero triunfó, con 90 votos, la opinión de cesarlos, defendida por el consejero Jaime Aguilar. AMV. PQ, B-14.

35. AMV. $M C, \mathrm{~A}-59$, fol. $61 \mathrm{v}$.

36. Inmediatamente, alguno de los asistentes denunció que el jurista micer Bartolomé Camós no podía desempeñar el cargo al no haber residido en la capital más de veinte años, pero dos consejeros, Bartolomé Coll de Sanç y Jaime Gisbert, testificaron la residencia de este en Valencia durante más de dos décadas. AMV. MC, A-59, fol. 50.

(C) Ediciones Universidad de Salamanca / ®@ Stud. his., H. ${ }^{a}$ mod., 38, n. 1 (2016), pp. 319-350 
de votos, convirtiéndose en los nuevos abogados de la Ciudad ${ }^{37}$. Micer Bartolomé Monfort solo se mantuvo en el puesto un año, pues en el Consell General del 19 de junio de 1521 fue cesado junto con micer Dimas de Aguilar. En el caso de micer Aguilar se alegó su despreocupación y en el de micer Monfort su negativa a jurar el cargo ${ }^{38}$. Para el nombramiento de los sustitutos se facultó a los jurados y a un grupo de consejeros para que eligieran a los que estimaran más oportunos ${ }^{39}$. Los nuevos abogados de la Ciudad -don Pedro Luis Sanç y micer Bernardo Soriano-, fueron nombrados el 26 de junio de 1521. A la mañana siguiente, debido al silencio de don Pedro Luis Sanç a los sucesivos llamamientos realizados para que acudiera a jurar su cargo, fue cesado y sustituido por el consejero jurista micer Luis Cosme Abat, quien, a tenor de su escasa asistencia a las sesiones del Consell General, tampoco asumió plenamente su cometido ${ }^{40}$.

Micer Bartolomé Monfort y micer Jerónimo Soriano fueron los abogados titulares de la Germanía, redactando la mayor parte de los documentos emanados de la Junta de los Trece y demás cuestiones legales. Según Vallés Borràs, estos no fueron agermanados ni mucho menos ideólogos del movimiento, aunque sí gozaron de un gran influjo en el sector moderado de la Germanía ${ }^{41}$. En enero de 1520, en la segunda embajada que los agermanados enviaron a Carlos I, le solicitaron -a cambio de su respaldo a jurar los Fueros valencianos por medio de un delegado-, poder disponer nuevamente de las armas, que reformara la administración local y judicial, que solucionara la falta de moneda y que les autorizara a tener el asesoramiento legal de dos letrados ${ }^{42}$. Carlos I presionado por la falta de tiempo y las continuas negativas de los estamentos militar y eclesiástico a facilitarle su juramento, accedió a los requerimientos agermanados. Nada más llegar a Valencia para continuar las negociaciones, el regente del Consejo de Aragón, micer García Garcés de Jaime, nombró el 21 de febrero de 1520 como abogados del pueblo a micer Bartolomé Monfort y micer Jerónimo Soriano. Estos dos letrados ya se habían encargado del asesoramiento legal de los agermanados. Pero la coacción

37. Los votos se repartieron de la siguiente forma: micer Bartolomé Monfort, 96; micer Bartolomé Camós, 75; micer Francisco Esteve, 27; micer Damián Andrés, 14; micer Bartolomé Rodríguez, 9 y micer Francisco de Sent Feliu, 9. AMV. MC, A-59, fol. 50.

38. De hecho, este no asistió a ninguna de las reuniones del Consell General celebradas desde el 23 de junio de 1520 hasta el 19 de junio de 1521. Por el contrario, micer Aguilar durante la juradería de 1520-21 asistió a 8 de las 26 convocatorias del Consell General.

39. AMV. $M C, \mathrm{~A}-59$, fol. 40.

40. AMV. $M C, \mathrm{~A}-59$, fols. 48-50.

41. Vallés Borrás, V.: «Notarios y juristas al servicio de la Germanía», Estudis, 26, 2000, pp. 215-225.

42. Viciana, M. de: Crónica de la ínclita y coronada ciudad de Valencia, vol. IV, ed. Sebastián García Martínez. Valencia, 1972, fols. 14v-15v.

(C) Ediciones Universidad de Salamanca / ®@ Stud. his., H. ${ }^{a}$ mod., 38, n. 1 (2016), pp. 319-350 
de algunos nobles, clientes suyos, y el recelo a posibles represalias por parte de la Corona les hizo renunciar hasta que no conseguirse una confirmación de su cargo por parte del rey, como así se hizo ${ }^{43}$. No obstante, ante la radicalización de las posturas agermanadas, micer Monfort y micer Soriano presentaron al virrey, en reiteradas ocasiones, su renuncia como abogados del pueblo, hasta que finalmente entre mayo y julio de 1521 les fue concedida, tomándolos a su servicio. Decepcionados, los agermanados saquearon sus casas.

Nada más hacerse con el control de la capital, el virrey don Diego Hurtado de Mendoza, con el fin de controlar todos los niveles del gobierno municipal, ordenó el 12 de noviembre de 1521 la restitución en su cargo de los abogados de la Ciudad destituidos en 1520. Cumpliendo órdenes, los jurados cesaron a los tres letrados designados por los agermanados -micer Bernardo Soriano, micer Luis Cosme Abat y micer Bartolomé Camós-, volviendo a ejercer como abogados de la Ciudad micer Ausias Bosch, micer Francisco Ros ${ }^{44}$, micer Francisco d'Artés -que nunca lo perdió ${ }^{45}$ - y micer Dimas de Aguilar, quien, como sucedió en el periodo anterior, tuvo como delegado a don Pedro Luis Sanç ${ }^{46}$. Este, apoyado por el virrey, logró ser confirmado como abogado de la Ciudad el 23 de febrero de 1523 reemplazando a micer Ausias Bosch ${ }^{47}$. Elección sancionada, casi una década después, en el Consell General del 18 de mayo de $1532^{48}$.

43. Viciana, op. cit., fol. 17. Vallés Borràs, V.: La Germanía de Valencia. Valencia 2000, p. 152.

44. Gozó de una amplia confianza por parte de Carlos I y sus representantes en el reino, ingresando en la Real Audiencia en 1520. Abogado fiscal y patrimonial (1523-1532). Alcanzó plaza de oidor en la reforma de 1527, manteniéndose como magistrado hasta 1543. En la inspección iniciada por La Gasca en 1543 se le acusó de prosperar al amparo de la toga, abusando de su cargo en su condición de propietario de molinos, mercader en granos y tejidos y arrendatario del General. Canet Aparisi, T.: «La justicia del emperador. La refundación Carolina de la Audiencia valenciana», en Martínez Millán, J. (coord.): Carlos $V$ y la quiebra del humanismo político en Europa (1530-1558). vol. 2, Madrid, 2001, pp.186-189, 195.

45. La permanencia de micer d'Artés en el cargo durante la Germanía se debió a la conformidad del virrey, al considerarlo el más competente para que le revelara de todos los proyectos de los agermanados respecto al Municipio. Al descubrirse su doble juego y ante la llegada de los radicales, que lo amenazaron de muerte, a principios de julio de 1521 salió de la capital y marchó junto con el virrey. VAllés Borràs, op. cit., pp. 229-230.

46. Ambas resoluciones aparecen ampliamente detalladas en el Manual de Consells pero su lectura es muy complicada por el deterioro que sufre la mayor parte de este volumen. AMV. $M C$, A-59, fols. 606-607v y 610-611v.

47. El privilegio que lo confirmaba como abogado de la Ciudad fue dado por el rey en Valladolid el 20 de diciembre de 1522 y ejecutado el 23 de febrero de 1523. AMV. Cartas reales, h3-3, fols. $77 \mathrm{v}-78$. En esta juradería no solo sustituyó a micer Dimas de Aguilar sino también a micer Ausias Bosch, a quien reemplazó cuando fue nombrado abogado de la Ciudad. Micer Bosch ejerció como juez d'amprius y examinador de abogados en 1518-1519.

48. AMV. PQ, B-19.

(C) Ediciones Universidad de Salamanca / ®@ Stud. his., H. ${ }^{a}$ mod., 38, n. 1 (2016), pp. 319-350 


\section{Abogados EXTRAORdinARIOS y COADJUTORES}

La muerte de micer Francisco d'Artés el 7 de diciembre de 1537 tardó en ser cubierta $^{49}$. En el Consell General del 6 de febrero de 1538 se tomaron medidas para hacer frente a la falta de asesoramiento legal que sufría el Municipio, no solo por la muerte d'Artés -y complicada sustitución- sino también por la negativa de los otros abogados de la Ciudad a ejercer como tales. Se vivían además momentos complicados en temas como el conflicto con el duque de Segorbe por las baronías de Paterna, la Pobla y Benaguasil ${ }^{50}$. Por ello, el Consell General concedió poder al Consell Secret para que en caso de que los abogados de la Ciudad se negaran a ejercer fueran destituidos y pudieran nombrar otros:

la Ciutat té falta de advocats axi per mort de micer d'Artés, en loch del qual fins a huy no es feta electió, com encara perquè algú dels advocats ordinaris se scusa de aconsellar a la ciutat. [...] la Ciutat se troba en semblants necessitats i [...]té necessitat de amprar-se de advocats de fora de la cambra [...] placia us deliberar en semblants casos lo que és deu de fer axí respecte als advocats quis scusen o scuraran de defensar la dita Ciutat, com encara en altres persones elegidores per a defensar la dita causa y en la forma que-s deu tenir per a amprar-se de advocats fora de la cambra e de la satisfacció de aquells [...]. Consell General [...] dellibera en qualsevol cars que la dita Ciutat haurà de pledejar ab qualsevulla persona, collegi, sglésia i universitat que qualsevulla dels advocats de la ciutat qui recusarà de advocar, aconsellar $\mathrm{e}$ assessorar a la ciutat e altres qualsevols officials que recusaran de fer lo que deuen fer en defensió de la Ciutat [...] sien privats lo tal advocat o officials que no volrà advocar, aconsellar e defensar la Ciutat com de present lo priva el Consell General e revoca de advocat e del offici que tendrà de dita ciutat e en tal cars los jurats, racional, advocats e síndich puixen elegir hun altre en loch d'aquell ${ }^{51}$.

De acuerdo con este poder y para cubrir la falta de juristas padecida por el gobierno municipal, el 15 de marzo de 1538 los jurados, el racional y el síndico eligieron como abogado de la Ciudad, en sustitución del finado micer d'Artés, a

49. El 11 de diciembre de 1537 micer Dimas Aguilar fue nombrado nuevo abogado de Murs $y$ Valls. AMV. MC, A-69. El Consell Secret ordenó el 7 de diciembre pagar 30 ducados a un correo que marchó a la Corte con varias cartas, entre las que cuales se le comunicaba la muerte del abogado micer d'Artés. AMV. PQ, B-19. Micer d'Artés ejerció además como: examinador de notarios 1515-1516, 1525-1526, 1527-1528; corregidor de abogados 1527-1528 y 1535-1536; juez apelación d'amprius 1517-1518 y 1521-1522.

50. Valor Moncho, P.: «Tres Baronías y un conflicto. La pugna por la Pobla, Paterna y Benaguasil entre el Duque de Segorbe y Ciudad de Valencia (1500-1550)», en Franch, R.; ANDRÉs, F. y BeníteZ, R. (coords.): Cambios y Resistencias Sociales en la Edad Moderna: Un análisis comparativo entre el centro y la periferia mediterránea de la Monarquía Hispánica. Valencia, 2014, pp. 141-152

51. AMV. $M C, \mathrm{~A}-69$.

(C) Ediciones Universidad de Salamanca / ®@ Stud. his., H. ${ }^{a}$ mod., 38, n. 1 (2016), pp. 319-350 
don Jerónimo Centelles, quien juró ese mismo día introduciendo una cláusula en el juramento respecto a su anterior actuación como abogado del duque de Segorbe en el pleito que este mantenía con la ciudad de Valencia:

que en lo dit offici se haurà bé e lealment y advocarà a la Ciutat y donarà bons y leals consells a aquella en qualsevol plets que la dita Ciutat [...] tindrà contra qualsevol persones, juxta les ordinacions y stabliments fets per lo consell de la dita ciutat [...] lo qual dix que axí jura com allí se conté y que és veritat que ell ha entrevengut com advocat del excellent duch de Sogorb en la causa o causes que té contra la Ciutat y que aprés que tingué la sperança de ésser fet advocat de la ciutat ell se és inhibit de entrevenir en dita causa en favor del duch e que per ço en respecte de les dites causa e causes ell no entén quel jurament [...] puix és cosa que és de justícia».

A la mañana siguiente, los jurados, el racional y el síndico se mostraron contrarios a la respuesta dada por Centelles en su juramento, requiriendo al notario público que lo registrara para que quedara memoria ${ }^{52}$.

Tampoco estuvo exenta de polémica la elección el 27 de febrero de 1538, por el Consell Secret, de micer Cosme Abat como abogado extraordinario de la Ciudad para que les orientara sobre todo en el pleito que se mantenía con el duque de Segorbe. Tras la muerte de micer Francisco d'Artés, los jurados se habían quedado sin nadie que les aconsejara en este conflicto, puesto que dos de los tres abogados de la Ciudad que quedaban estaban involucrados. Don Pedro Luis Sanç era letrado del duque de Segorbe y micer Francisco Ros aconsejaba al duque de Calabria en este asunto. Ante tal panorama, los munícipes emprendieron una búsqueda entre los juristas de la capital y, después de varias negativas, lograron que micer Cosme Abat accediera, trabajando desde el 1 de diciembre en la defensa de los derechos municipales. La recompensa fue su nombramiento el 27 de febrero de 1538 como abogado extraordinario perpetuo, con los mismos salarios y preeminencias que los ordinarios, ofreciéndole además la primera plaza que quedara vacante de abogado ordinario de la capital:

E perquè la ciutat no reste ab salaris de més [...] preveheixen que vacant alguna de les advocacions ordinàries de avant per cessum vel decessum que lo dit micer Abat en tot cas reste en loch de tal advocat ${ }^{53}$.

52. AMV. $M C, \mathrm{~A}-69$.

53. Pagándole en marzo de 153820 libras «per la primera paga del salari del primer mig any». AMV. MC, A-69.

(C) Ediciones Universidad de Salamanca / ®@ Stud. his., H. ${ }^{a}$ mod., 38, n. 1 (2016), pp. 319-350 
Esta promesa despertó el malestar de los otros abogados de la Ciudad, por lo que el 8 de abril el Consell Secret, contando con el asentimiento de micer Abat, suprimió la condición cessum

atés que en la promisió per aquells feta de advocat extraordinari en la persona de micer Cosme Abat a XXVII de febrer propasat se diu que lo dit micer Abat post cesum vel decessum de qualsevol dels quatre advocats ordinaris de la dita ciutat subintras e fos posat en la de aquell e vehent molt clarament que la dita clàusula quant se diu per cessum no és contra forma a justícia e per altres justes causes e rahons, proveheixen e nom de voluntat del dit micer Abat, que's present al fer de la present promisió, que la dita clàusula per cessum sia haguda per no posada, feta ne aprovehïda e aquella ningun effecte puixa obrar en favor del dit micer Abat ni en res ni per res prejudicar als dits quatre advocats ordinaris.

A la mañana siguiente, en Consell General se confirmó el nombramiento como abogado extraordinario de la Ciudad de micer Abat, a pesar de la oposición de don Pedro Luis Sanç quien se mostró contrario a la cláusula de per decessum.

lo que és del parer que sia confermada la electió de micer Cosme Abat advocat extraordinari emperò quant a la clàusula de per decessum no és de parer que sia en dita electió per quant aquella no sols lo par que no és conforme a rahó ni justícia parlant ab lo acatament que's pertany [...] als quatre advocats ordinaris de la ciutat ${ }^{54}$.

Nueve meses más tarde, el 4 de diciembre de 1538, los jurados, de acuerdo con el poder concedido por el Consell General del 6 de febrero de 1538, designaron a micer Cosme Abat como abogado ordinario de la Ciudad, tras la muerte de don Jerónimo Centelles ${ }^{55}$.

Los años empezaron a pesar en los abogados de la Ciudad, quienes a partir de 1545 presentaron varias solicitudes al Consell Secret para contar con un coadjutor a su cargo, que normalmente pasaba a tener el cargo en propiedad a la muerte de su titular. En la mayoría de estas peticiones, se alegaba la excesiva carga laboral, los achaques de la edad y los múltiples servicios prestados a la capital para que se les concediera la colaboración de un auxiliar, con el que ejercería el cargo conjunta o separadamente, no percibiendo este ninguna remuneración. Demandas siempre aceptadas por los magistrados municipales y refrendadas por el Consell General, entre otras razones por la falta de asesores legales y el escaso interés que tenían otros juristas en ocupar este cargo.

54. AMV. $M C, \mathrm{~A}-69$.

55. AMV. $M C, \mathrm{~A}-70$.

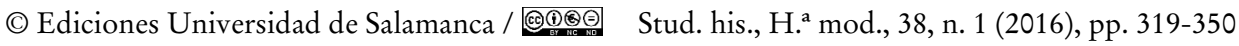


Fue el caso de micer Francisco Ros, quien solicitó el 3 de octubre de 1545 poder compartir el cargo con micer Diego Pérez de Ystella, con quien también trabajaba en la Real Audiencia, ya que la edad y las enfermedades le impedían cumplir con todas las labores propias del puesto ${ }^{56}$ :

com ell havia més de treinta anys que servia a la ciutat de advocat y que ell en dit temps la havia servida en tot allò que ad aquell possible li era estat segons per experiència se és vist y com aquell se veja ja vell y malalt de moltes malalties y questant malat no pot servir la dita ciutat segons ell volria y té acostumat y com ell haja pensat que prestant ell son consentiment per a que algú doctor lo qual fos tal qual convingués per al dit offici fos coadjunt ab aquell en dit offici seria millor servida la dita ciutat y ell haja mirat qual dels doctors de la present ciutat seria més convenient y profitós a la dita ciutat y com en la present ciutat juxta sa conciència no troben persona alguna la qual més comodaria y que més conviga a la dita ciutat sinó del dit magnífich micer Diego Pérez de Ystella, cavaller y doctor en cascum dret per a ques haja de fer la dita coadjunció ${ }^{57}$.

Súplica aceptada por los jurados, el racional y el síndico al considerar que no solo era una manera de gratificar a micer Francisco Ros por sus muchos servicios, sino que también podía servir de aliciente para aquellos que se mostraban remisos a trabajar para la capital

com sia rahó conforme y convé a la reputació de la dita ciutat perquè altres se animen de fer semblants coses que semblant persona la qual li haja fet tants serveys per tant temps senta alguna gratifficació.

Por todo ello, en virtud del poder dado en el Consell General de 30 de junio de 1435, el Consell Secret eligió como abogado de la Ciudad a micer Diego Pérez de Ystella junto con micer Francisco Ros,

en axí que los dos juntament y cascú per si tinguen, serveixquen y regeixquen lo dit offici de advocat de la ciutat y desfallint lo altre de aquells reste lo dit offici de advocat $[\ldots]$ en lo sobrevivent a soles. En axí los dos no hagen sinó un sols salari $[\ldots]$ emperò tinguen totes les honors, preheminències, favors y prerrogatives del dit offici de advocat de la dita ciutat.

56. Diego Pérez de Ystella había ingresado en la Real Audiencia en 1535. CAnEt Aparici, T.: «La justicia del emperador...», pp. 179, 182, 189. Micer Cosme Abat ejerció como: asesor de justicia civil 1525-1526; asesor justicia criminal 1531-1532 y 1535-1536; corregidor de abogados 1537-1538, 1541-1542 y 1544-1545; juez d'amprius 1541-1542; examinador de notarios 1538-1539 y $1543-1544$.

57. AMV. $P Q$, B-30. Micer Pérez de Ystella ejercicio además como corregidor de abogados en 1545-1546 y 1546-1547 y como juez d'amprius $1545-1546$ y $1547-1548$.

(C) Ediciones Universidad de Salamanca / ®@ Stud. his., H. ${ }^{a}$ mod., 38, n. 1 (2016), pp. 319-350 
Acto seguido, Pérez de Ystella se personó en la sala del Consell Secret donde se le comunicó el nombramiento y juró ejercer correctamente el cargo, dando buenos consejos, guardando secreto de todo lo que se le dijera y respondiendo siempre que fuera requerido por los dirigentes municipales. Dos meses más tarde, en el Consell General del 22 de diciembre de 1545, se refrendó este nombramiento ${ }^{58}$.

Justo un año más tarde otro de los abogados de la Ciudad, micer Cosme Abat, requería que micer Pedro Juan de Capdevila pudiera ejercer como auxiliar con razonamientos parecidos a los esgrimidos por micer Ros: las dolencias, los años y el importante volumen de trabajo al que tenía que hacer frente. Solicitud aceptada por el Consell Secret del 15 de diciembre de $1546^{59}$. Pero esta colaboración solo duró un mes, pues el 11 de enero de 1547, al fallecer micer Abat, micer Capdevila fue nombrado abogado ordinario de la Ciudad, siguiendo el consejo de micer Ystella de que, a pesar de que Capdevila era coadjutor, debía procederse a una nueva designación:

que tenen per bé per conservació dels privilegis, stabliments, ordinacions, usos e bons costums e possessió e altres que la ciutat té en fer elegir advocats e altres officials de dita ciutat en cas de vacació de dits officis se faça novament electió de advocat de la dita ciutat per mort de micer Cosme.

Designación aceptada por micer Capdevila, a pesar de que él ya se tenía como abogado de la Ciudad ${ }^{60}$.

No se cumplía, por tanto, con los deseos del virrey, quien nada más morir micer Abat escribió al príncipe el 7 de enero para pedirle que, en su lugar, nominara a Pedro de Moncada como abogado de la Ciudad, recordándole que era prerrogativa de la Corona proveer este cargo y no podía permitir que la designación estuviera en manos de los dirigentes capitalinos. Una candidatura, la de Pedro de Moncada, que ya defendió cuando se temía por la muerte de micer Ros y que fue aceptada, aunque no se pudo llevar a cabo al no producirse el previsible óbito. Aprovechó también esta misiva para arremeter contra las coadjutorías, nunca admitidas por la Corona:

los días pasados estando para morir miçer Ros huno de los advogados de la desta çiudad escreví e imbié a suplicar a Vuestra Altesa me hiziesse merced de su advocaçión

58. AMV. PQ, B-30. En el Consell Secret del 14 de febrero de 1549 se determinó pagar a micer Diego Pérez de Ystella ya que era coadjutor sin salario alguno y continuamente estaba sirviendo a la Ciudad. AMV. MC, A-76, fol. 248. El 11 de agosto de 1548 este jurista presentó ante los jurados, el racional y el síndico un privilegio firmado por el príncipe Felipe sobre su cargo de abogado de la ciudad, junto con micer Ros. AMV. Cartes reials, h3-4, fols. 126v-127.

59. AMV. $P Q, \mathrm{~B}-31$.

60. AMV. $P Q, \mathrm{~B}-31$.

(C) Ediciones Universidad de Salamanca / ®@ Stud. his., H. ${ }^{a}$ mod., 38, n. 1 (2016), pp. 319-350 
y offiçio para don Pedro de Moncada por ser muy buen letrado y cavallero de buena conciençia y rectitud que es lo que principalmente ha menester la Sala desta çiudad por hir desordenada y mal regidas las cosas della y fueme respondido que Vuestra Alteza havía sido contento de hazerme la merced en persona del dicho don Pedro la qual tuve yo en tanto hera razón y quiso su ventura quel dicho miçer Ros no murió sino que vive y está para vivir muchos años. En este día muerto miçer Abat hotro advogado desta çiudad por cuya muerte vaca hotro offiçio de advocaçión en el qual çertiffico a Vuestra Altesa que no puede entrar persona más conveniente ni que más importe para la refformaçión de las cosas de dicha çiudad que lo han bien menester que la del dicho don Pedro. Y assí suplico a Vuestra Altesa muy humildemente me haga merced de la dicha advocaçión que vaca para él porque la reçebiré yo muy propia allende que como tengo dicho en ninguno de quantos la piden será tan bien enpleada y proveyda como en él. Y si los jurados de dicha çiudad pretendieren que pueden proveer semejantes offiçios acuérdesse Vuestra Altesa que por provissión de Su Majestad les está mandado que no lo hagan ni se entremetan en ellos y assí lo hazen ahunque contra su voluntad y si quisieren allegar coadjutorías tanbién están proybidas por Su Majestad y ninguna se ha admittido en este Reyno muchos años ha ni se deven admittir pues se vee claramente que Su Majestad no es servido de ellas ${ }^{61}$.

Denuncia que no debió prosperar y de la que no hemos encontrado rastro documental. En los múltiples enfrentamientos que a lo largo del reinado de Carlos I mantuvo la Ciudad con la Corte por el nombramiento de cargos municipales, nada se alude a la intromisión regia en la designación de los abogados de la Ciudad.

La gran labor ejercida por micer Juan Bautista Paredes en la embajada que los tres estamentos enviaron al príncipe Felipe, en febrero de 1548, para que pusiera fin a la comisión de micer Onofre Urgellés, le valió su nombramiento como abogado extraordinario en el Consell Secret del 23 de marzo de ese mismo año. Durante los preparativos de la citada comisión, los abogados de la Ciudad se desentendieron totalmente, alegando motivos diversos. Por ello, desesperados, los jurados buscaron la colaboración de otros juristas. Aunque solo respondió favorablemente micer Paredes, quien no defraudó en su trabajo. Como recompensa, se decidió su mención -por motivos económicos-, como abogado extraordinario con la promesa de hacerlo ordinario cuando se diera alguna vacante:

fer dita embaxada en la qual ningun advocat de la ciutat y volgué anar essent-ne requests per ses magnificències al-legant huns malalties, altres diverses escuses per hon fonch forçat haver de cercar advocats estranys per anar ab dita embaixada. E com per dita rahó diversos advocats de la present ciutat requests e pregats se escu-

61. AGS. Estado, leg. 300, doc. 149.

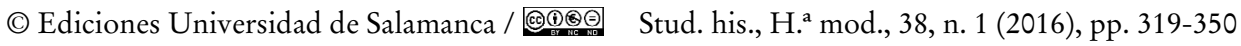


saren de fer dita anada vent que los advocats de la dita ciutat se escusaren de anar en dita embaixada sinó fonch lo magnífich micer Johan Baptiste Paredes, doctor en cascun dret, lo qual se offerí de anar en dita embaixada y treballar en totes ses forces en tot lo que tocàs al benefici de la dita ciutat e regne de manera tal que la dita comissió fos revocada o obtés sobresehïment en aquella. Axi lo dit micer Paredes fonch elet per a la dita embaixada en la qual aquell és anat a la cort del príncep ab los missatgers per los estaments a hon treballar, informar e fet tot allò que hum solempne doctor podia e devia fer segons per relació dels dits missatgers són estats informats en tal manera que se ha obtés sobresehïment en dita comissió e ab aquell la ciutat se ha reposat e los comersis de aquella restituhït [...] E com sia a rahó conforme que lo dit micer Paredes sia gratifficat del dit servey fet a la dita ciutat y essent com és lo dit micer Paredes doctor tant solempne convendria molt que la ciutat lo tingués per advocat ab la qual no sols la dita ciutat seria ben servida de aquell sinó en lo que toca a advocar-li però ab aquella aquell serà gratifficat de dit servey. E serà animar als altres de servir a la dita ciutat en semblants e altres affers de la dita ciutat e regne. Per ço, per virtut del poder del Consell General celebrar a XXX de juny any MCCCCXXXV, elegeixen en advocat extraordinari de la dita ciutat al dit micer Johan Baptiste Paredes absent ab salari de vint lliures cascum any. E present que los altres advocats acostumen de rebre. E per que la ciutat no reste $\mathrm{ab}$ salaris demasiats preveheixen que vacant alguna de les advocacions ordinàries de la dita ciutat de huy avant per cessum vel decessum que lo dit micer Paredes en tal cars succehixca y reste en lloch del tal advocat ab lo salari, llibertats y prerrogatives que cascú dels altres advocats acostumen tenir ${ }^{62}$.

El nombramiento de micer Capdevila como oidor de la Real Audiencia ${ }^{63}$ y la ancianidad de los otros tres abogados de la Ciudad -micer Francisco Ros, micer Dimas Aguilar y don Pedro Luis Sanç- ${ }^{64}$ dejaba muchas veces desprotegida jurídicamente a la capital, por lo que el Consell Secret del 8 de agosto de 1551 nombró a otro abogado extraordinario, ya que el existente -micer Juan Bautista Paredes-, también prestaba sus servicios en la Real Audiencia ${ }^{65}$. El designado fue el noble don Pedro de Moncada, percibiendo anualmente 20 libras $^{66}$. Elección sancionada,

62. El abogado elegido inicialmente para integrar la embajada fue micer Dimas Aguilar quien no participó alegando su edad. AMV. MC, A-75, fol. 275, 321.

63. Febrer Romaguera, M.: «Pere Joan de Capdevila, catedrático y abogado (hc. 1495-1558): biografía y estudio bibliográfico de su biblioteca jurídica», en Congreso Universitario de Ciencias de la Documentación, vol. 1. Madrid, 2000, pp. 197-237.

64. «los quals bonament no poden servir a la ciutat com voldrien [...] són vells e ha molts anys que serveixen a la ciutat e micer Pere Joan Capdevila ara novament és elet en un dels doctors del real consell». AMV. $M C, \mathrm{~A}-77$, fol. 339.

65. CANET Aparici, T.: «Entre la visita y la sucesión. La resistencia a la virreinalización administrativa en Valencia entre Carlos V y Felipe II», Estudis, 28, 2002, pp. 226-229.

66. AMV. $M C, \mathrm{~A}-77$, fols. 339 y $535 \mathrm{v}$.

(C) Ediciones Universidad de Salamanca / ®@ Stud. his., H. ${ }^{a}$ mod., 38, n. 1 (2016), pp. 319-350 
pocos días después, en el Consell General de la vigilia de la Asunción ${ }^{67}$. Posteriormente, al ser llamado a la Corte para formar parte del Consejo de Aragón, Moncada solicitó que durante su ausencia su puesto fuera encomendado a micer Jerónimo Aliaga; petición que fue aceptada el 5 de mayo de $1554^{68}$.

También en el Consell Secret del 8 de agosto de 1551 se dio luz verde al ruego de don Pedro Luis Sanç para tener como auxiliar a micer Francisco García Trujillo simul et insolum, agradeciendo de esta manera las casi tres décadas de trabajo del primero a favor de la capital ${ }^{69}$. Resolución reafirmada en el Consell General del 28 de septiembre de $1551^{70}$. Ese mismo año otro de los sempiternos abogados de la Ciudad, micer Dimas Aguilar, demandaba que micer Miguel Ángel Català fuera coadjutor a su cargo. Instancia aceptada, en virtud del poder de 1435, por el Consell Secret del 13 de noviembre de 1551 y avalada en el Consell General del 22 de diciembre de ese mismo año ${ }^{71}$. Ambos ejercerían juntos o por separado y percibiendo un único salario. Solo un año después, en diciembre de 1552, fallecía micer Aguilar, restando el cargo para micer Miguel Ángel Català, quien además asumiría la condición del finado de abogado de la Fábrica de Murs y Valls ${ }^{72}$. El 10 de septiembre de 1555, el mismo día de la muerte de micer Català, el Consell Secret distinguía como abogado de la Ciudad al hasta entonces abogado extraordinario

67. «[...] com los quatre advocats ordinaris de la ciutat sien impedits per antiguitat de dies y lo hu resta en al Real Audiència, la ciutat tinga moltes causes e de importància les quals convé sien defensades, per dita rahó han fet advocat extraordinari a don Pedro Moncada [...] los jurats a major cautela los par donar-ne rahó al dit Consell sils parexa loar e aprobar la electió» AMV. $M C$, A-77, fol. 346.

68. AMV. $M C, \mathrm{~A}-78$.

69. AMV. $M C, \mathrm{~A}-77$, fols. 340v-341.

70. AMV. MC, A-77, fol. 370. El 19 de diciembre de 1554 el Consell Secret decidió abonar a micer Francisco García de Trujillo 15 libras «lo qual és coadjunt ab lo noble don Pere Luis Sanç, [...] sens percibir ningun salari», ya que continuamente estaba sirviendo y aconsejando a la capital, sobre todo en los pleitos de los impuestos de Benito Vallaclocha y sobre el trigo de Luís Macip y Miguel Salvador. AMV. PQ, B-34.

71. Las razones alegadas fueron similares a en otras ocasiones: la edad; sus achaques; los muchos servicios a la capital durante 32 años y la obligación de corresponderle de algún modo; la suficiencia de micer Miguel Ángel Català y la necesidad de que la capital estuviera mejor asesorada. AMV. MC, A-77, fols. 401 y 436. Micer Aguilar ejerció además como: examinador de abogados en 1518-1519, 1523-1524, 1532-1533, 1536-1537, 1543-1544, 1548-1549; juez d'amprius 1520-1521, 1523-1524, 1525-1526, 1538-1539, 1542-1543, 1546-1547, 1549-1550; examinador de notarios 1518-1519, 1522-1523, 1529-1530, 1536-1537, 1541-1542, 1544-1545, 1547-1548; asesor justicia criminal 1529-1530, 1537-1538, 1542-1543 y $1545-1546$.

72. AMV. $M C, \mathrm{~A}-78$, fol. 268. Ejerció como asesor del justicia civil en la juradería de 15531554; corregidor de abogados en 1543-1544, 1547-1548, 1551-1552 y 1554-1555; examinador de notarios en 1551-1552 y 1554-1555; juez d'amprius en 1552-1553.

(C) Ediciones Universidad de Salamanca / ®@ Stud. his., H. ${ }^{a}$ mod., 38, n. 1 (2016), pp. 319-350 
micer Juan Bautista Paredes ${ }^{73}$. Igualmente, este fallecimiento dejaba vacante el puesto de abogado de la Fábrica de Murs y Valls, iniciándose un enfrentamiento entre los jurados y los obreros de la citada Fábrica que se prolongó hasta $1557^{74}$.

El último de los abogados que permanecían en el cargo desde la época de la Germanía, micer Francisco Ros, solicitó en febrero de 1556 poder compartir su cargo con micer Martín Pons, abogado fiscal y patrimonial del rey, aduciendo como todos los casos anteriores la incapacidad de poder cumplir con las necesidades de la ciudad por edad y achaques. Una década antes ya había solicitado y se le había sido concedido ser auxiliado por micer Diego Pérez de Ystella, desconociendo el periodo de duración de esa colaboración. Ahora, de nuevo, el Consell Secret aceptaba que tuviera un coadjutor, en este caso a micer Martín Pons; refrendado por el Consell General del 11 de ese mismo mes ${ }^{75}$. La muerte de micer Ros -cuya fecha no hemos podido averiguar-, convirtió en abogado de la Ciudad a micer Pons, quien el 5 de junio de 1557 solicitó y logró que micer Jerónimo Aliaga ejerciera como coadjutor ${ }^{76}$. Decisión aprobada días después en el Consell General del 23 de junio ${ }^{77}$.

73. AMV. $M C, \mathrm{~A}-80$, fol. 173. Ejerció como asesor del justicia civil en 1523-1524, 1529-1530 y 1544-1545; asesor justicia criminal 1540-1541; examinador de notarios 1545-1546; corregidor de abogados 1546-1547.

74. El 21 de octubre de 1555 los jurados y el racional en presencia del canónigo Domingo de Ribelles -subdelegado del obrero por el estamento eclesiástico-, mosén Gaspar Antich -obrero por el militar-y Gaspar de Artés -obrero por el real- eligieron en abogado de la Fábrica de Murs $i$ Valls a micer Francisco Ros. Nombramiento que no fue aceptado por los obreros que eligieron a micer Jaime Filibert, no llegándose a ningún acuerdo. Meses más tarde, el 16 de marzo de 1556 los nuevos obreros -mosén Cristóbal Frigola, don Jaume Corberan y Gaspar de San Pere- junto con los jurados decidieron revocar la elección de micer Ros y micer Filibert, quedando vacante el cargo. AMV. MC, A-80, fols. 208, 433v. Tuvo que pasar un año para que el 6 de mayo de 1557 los jurados y el racional acordaran con los obreros de la Fábrica de Murs y Valls nombrar como abogados de la misma a don Pedro Luis Sanç y mosén Jaime Filibert simul et insolum. Además, atendiendo a la labor desempeñada por micer Miguel Ángel Català, se eligió como coadjutor de ambos abogados a su hijo, Vicente Ferrer Català, que en el caso de ser jurista pudiera ejercer el cargo de abogado de la Fábrica de Murs y Valls, tras la muerte de Sanç y Filibert. AMV. MC, A-81, fol. 354

75. AMV. $M C, \mathrm{~A}-80$, fols. 356v-358.

76. AMV. $M C, \mathrm{~A}-81$, fol. $395 \mathrm{v}$. Detentó la catedra de Derecho Canónigo desde el curso 15411542 hasta 1558. Catedra del Derecho Civil 1559-1560. Felipo OrTs, op. cit., pp. 177-180. Ejerció además como jurista en el examen de notarios en 1537-1538, 1540-1541, 1548-1549 y 1551-1552; corregidor de abogados en 1538-1539 y 1544-1545; asesor del justicia criminal 1543-1544, 15471548 y $1554-1555$.

77. AMV. MC, A-82, fol. 37. Martín Pons fue miembro de una familia muy destacada al servicio de la Corona. Actuó durante años, adjunto a su padre Martín Pons de Castellvi, como abogado fiscal y patrimonial, para luego ejercer el cargo en solitario hasta que en 1576 fue promovido a la sala civil de la Audiencia y al Consejo Supremo de Aragón en 1581. CANET AparisI, T.: «La abogacía

(C) Ediciones Universidad de Salamanca / ®@ Stud. his., H. ${ }^{a}$ mod., 38, n. 1 (2016), pp. 319-350 
A mediados de agosto de 1557 dos de los abogados de la Ciudad -micer Capdevila y micer Paredes- solicitaron al Consell Secret tener un coadjutor. En el caso del primero, el día 11 el Consell Secret -en virtud del poder de 1435 y teniendo en cuenta los muchos servicios que durante años había prestado-nombró abogado de la Ciudad a su hijo, micer Jaime Juan Tomás de Capdevila con la condición de que:

regixquen en lo dit offici de advocat de la dita ciutat ab hun sols salari e emoluments al dit offici pertanyents e defallint lo un de aquells reste lo dit offici de advocat en lo sobrevivent a soles ${ }^{78}$.

A la mañana siguiente, el Consell Secret también admitió la petición de micer Juan Bautista Paredes de tener como auxiliar a micer Ambrosio Roca ${ }^{79}$.

Meses más tarde, en plena incidencia de la peste de 1557, estos dos abogados de la Ciudad -junto con sus coadjutores-y don Pedro Luis Sanç fueron revocados por cuanto habían abandonado la capital, negándose a regresar para aconsejar a los jurados a pesar de los dos requerimientos que se les habían mandado. Debido a este desamparo y teniendo en cuenta que otros oficiales tanto reales como municipales continuaban en sus puestos a pesar de la amenaza, los magistrados municipales los cesaron el 6 de noviembre de 1557, manteniendo a micer Martín Pons y su coadjutor

per la qual rahó hui resten ses magnificències sens advocat algú de la dita ciutat de qui puguen rebre consell considerant que lo spectable regent lo loctinent general ha residit e huy en dia residix, e lo magnífich regent la cancilleria que és lo magnífich micer Gaspar Ferrer e algú dels doctors del Real Consell han residit e residixen en la present ciutat et etiam lo revent senyor inquisidor ha residit e huy en dia residix en la present ciutat $\mathrm{e}$ altres persones que foren aquells comunicats per ses magnificències e ans e après contínuament han residit tot los dessús dits e altres persones de calitat en la present ciutat. Per ço et altres per moltes altres coses lo ànimo de ses magnificències $[\ldots]$ revoquen als dits don Pere Luis Sanç, micer Pere Johan Capdevila e micer Johan Baptiste Paredes, advocats de la dita ciutat revocant etiam los coadjunts de aquells volent e manant que de huy avant no reben salaris ni emoluments alguns de la dita ciutat.

fiscal: ¿una figura conflictiva en la administración valenciana?», en NARBONA VizCAínO, R. (coord.): La Mediterrània de la Corona d'Aragó, segles XIII-XVI, vol. 1. Valencia, 2004, pp.529-533.

78. AMV. $M C, \mathrm{~A}-82$, fol. 69v. Pedro Juan de Capdevila fallecía víctima de la peste en septiembre de 1558, continuando su hijo como abogado de la Ciudad. Febrer Romaguera, M. V.: «Pere Joan de Capdevila...», p. 23. Ejerció además de: asesor justicia civil 1527-1528, 1533-1534, 15481549; asesor justicia criminal 1536-1537; corregidor de abogados 1545-1546, 1547-1548, 1550-1551; juez d'amprius 1550-1551; examinador de notarios 1541-1542, 1546-1547 y 1549-1550.

79. AMV. $M C, \mathrm{~A}-82$, fol. 70. A la muerte de micer Paredes, micer Ambrosio Roca continuó ejerciendo el cargo. FELIPO ORTS, op. cit., p. 23.

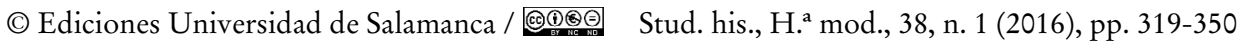


Además, se determinó que micer Juan Sentis asumiera el cargo de abogado de la Ciudad como gratificación a la labor que había desarrollado en los momentos en que otros habían hecho dejación de funciones ${ }^{80}$.

A los destituidos la noticia les fue comunicada días más tarde, el 19 de noviembre $^{81}$. Solo dos meses después volvían a recuperar su puesto después de ser aceptadas, por el Consell Secret del 7 de enero, las alegaciones que presentaron. En primer lugar se leyó el testimonio de don Pedro Luis Sanç dado nada más recibir la notificación del cese, argumentando que los médicos le habían aconsejado que, ante el agravamiento de su enfermedad abandonara la capital. Una salida que no sirvió de mucho, pues murió durante el mes de diciembre ${ }^{82}$. Por su parte, micer Pedro Juan de Capdevila alegó que había escrito al jurado mosén Guillermo Ramón Català indicándole que en el momento en que la Ciudad lo necesitara él acudiría, pero nadie lo recordó el día de los apartamientos ${ }^{83}$. Mediante testigos, micer Juan Bautista Paredes probó que, a pesar de que una antigua dolencia en la pierna le impedía, prácticamente, responder a las dos intimidaciones enviadas por los magistrados municipales, había acudido a la capital aún a riesgo de perder la vida. Hecho que los jurados desconocían:

testimonis que ha adonat per los quals ha mostrat que al temps que ses magnificències lo trameteren a demanar axí la primera vegada com la segona stava tant mal de una malaltia vella que té en la cama que stigué en punt de perdre la cama. E que no sols no stava per a venir a València però que vingué en molt perill de sa vida la qual cosa ses magnificències ignoraren.

Por su parte, los coadjutores -en nombre de los cuales se personó micer Trujillo- alegaron que estando como estaban en la capital desconocían las necesidades

80. AMV. $M C$, A-82, fols. 104v-105. Fue asesor del justicia civil en 1547-1548 y 1552-1553; examinador de notarios en 1552-1553; corregidor de abogados en 1551-1552 y 1557-1558.

81. El 25 de noviembre de 1557 el Consell Secret ordenó pagar al verguero Gaspar Roca 3 libras, 3 sueldos y 9 dineros por su visita a Xàtiva y otros lugares para comunicar a don Pedro Luis Sanç, micer Pedro Juan Capdevila y micer Juan Bautista Paredes su revocación. Durante su misión sufrió el ataque de unos ladrones por lo que además se le pagó «una capa gascona y diners que lladres li han robat e pres en dit viatge». AMV. MC, A-82, fol. 114.

82. Ejerció como: corregidor de abogados 1519-1520, 1521-1522, 1522-1523, 1525-1526, 1528-1529, 1531-1532, 1534-1535, 1538-1539, 1541-1542, 1548-1549, 1552-1553 у 1555-1556; examinador de notarios 1521-1522, 1524-1525, 1527-1528, 1530-1531 1533-1534, 1537-1538, 1540 1541 y 1550-1551; asesor justicia criminal 1517-1518; asesor justicia civil 1528-1529, 1534-1535, 1540-1541 y 1551-1552; juez d'amprius 1528-1539, 1529-1530, 1539-1540, 1548-1549 y 1551-1552.

83. «que ell scrigué al jurat mosèn Guillem Ramon Català quel avisas que si tanta necessitat tenia la Ciutat de sa persona que ell vendria a hon la Ciutat manarà de la qual lletra [...] ne feu exhibició a ses magnificències. E en après al temps de dita revocació no sén recordà nengú». AMV. $M C$, A-82, fol. 151.

(C) Ediciones Universidad de Salamanca / ®@ Stud. his., H. ${ }^{a}$ mod., 38, n. 1 (2016), pp. 319-350 
de los dirigentes municipales pues de lo contrario hubieran acudido en su auxilio, sin mediar aviso:

E los coadjuts se justificaren en que dihent que ells no tenen salari e [...] que fossen obligats vinint sos principals. E residint en la present ciutat nomenys foren convocats pera haver de venir ni tingueren notícia que la dita ciutat tingués necessitat de aquells lo que sin saberen foren venguts sense ser convocats senyaladament ${ }^{84}$.

Consideradas como justas estas disculpas y teniendo en cuenta la decisión del Consell General del 14 de agosto de 1557, en la que se determinaba el gobierno de la capital ante la hipotética salida de la urbe de las autoridades reales y municipales a causa de la peste ${ }^{85}$, el Consell Secret decidió readmitir en el cargo de abogado de la Ciudad a micer Capdevila y micer Paredes y auxiliares ${ }^{86}$. Además, nombraron a micer Francisco García Trujillo -coadjutor de don Pedro Luis Sanç desde el 8 de agosto de 1551-, nuevo abogado de la Ciudad ${ }^{87}$. Este restablecimiento provocó el cese en el Consell Secret del 15 de enero de 1558 de micer Juan Sentís, pretextándose que no era necesario gravar al Municipio con un mayor número de abogados e irregularidades en su nombramiento:

no tenint tanta necessitat com en salaris e despesses senyaladament essent estada feta la dita electió del dit micer Joan Sentis sens precehir convocació e sens ésser en aquella les persones que havien de concórrer per a poder-se fer dita electió conforme al poder donat en el Consell General celebrat a XXX de juny del any mil CCCCXXXV ${ }^{88}$.

Micer García Trujillo solo pudo disfrutar del cargo cuatro meses. Tras su óbito, en mayo de 1558, los jurados designaron a micer Pedro Benavent, quien desde el

84. AMV. $M C, \mathrm{~A}-82$, fol.151.

85. En el Consell General del 14 de agosto de 1557 se expuso que, posiblemente, debido a la peste muchos oficiales reales y municipales abandonarían la ciudad y se desperdigaran, de tal manera que sería muy complicado que el Consell Secret se pudieran reunir fácilmente. Por ello, el Consell General decidió que el racional convocara a los jurados y al síndico en los lugares y los días libres del peligro epidémico y si todos no podían acudir, en tal caso y mientras se mantuviera la amenaza de peste, se tuvieran por buenas las decisiones que se tomaran por los que estaban presentes, teniendo tanto valor como si estuvieran todos. AMV. MC, A-82, fol. 73.

86. Micer Paredes ejerció como: asesor justicia civil en 1523-1524, 1529-1530, 1544-1545; asesor justicia criminal 1540-1541; corregidor de abogados 1546-1547 y examinador de notarios $1545-1546$.

87. AMV. MC, A-82, fol. 151. Ejerció como asesor de justicia criminal 1549-1550 y 1555-1556; examinador de notarios 1552-1553 y corregidor de abogados 1556-1557.

88. Además de las 20 libras que había ya recibido, se le dieron otras tantas por todos los trabajos que había realizado hasta esa jornada. AMV. MC, A-82, fol. 155.

(C) Ediciones Universidad de Salamanca / ®@ Stud. his., H. ${ }^{a}$ mod., 38, n. 1 (2016), pp. 319-350 
mismo día de su nombramiento tuvo como coadjutor a micer Sent Joan Aguirre ${ }^{89}$. Decisiones corroboradas en el Consell General del 28 de mayo de $1558^{90}$.

A pesar de que en la mayor parte del periodo analizado la ciudad de Valencia contó con la asistencia jurídica de cuatro abogados ordinarios y dos extraordinarios, a veces no eran suficientes para atender todos los asuntos, por lo que se requería los servicios de otros juristas. Fue el caso del micer Jaime Mascarell y micer Jaime Gascó, quienes en abril de 1550 fueron remunerados por intervenir en la apelación presentada ante una sentencia dada por el racional a favor de la ciudad de Alicante ${ }^{91}$. En otras ocasiones, la búsqueda de ayuda externa se debía a la inhibición de los abogados de la Ciudad, que se negaban a asesorar a los dirigentes capitalinos. Así, por ejemplo, se produjo en los inicios de la juradería de 1535 a 1536 cuando micer Francisco d'Artés, micer Dimas Aguilar y don Pedro Luis Sanç se negaron a aconsejar a los jurados sobre las garantías presentadas por los clavarios, los cajeros mayores de la Taula de Canvis y el administrador de la Lonja, al considerar que no era su competencia, dejando claro en un escrito presentado el 28 de mayo que ellos se encargaban de asesorarles en la correcta provisión de los diferentes oficios municipales y en toda cuestión legal, pero no en materia de fianzas ${ }^{92}$.

Debido a las reiteradas faltas de respuesta de los abogados, la Ciudad los denunció ante las Cortes Generales de 1547, solicitando que se les pudiera multar por su desidia. Así en el capítulo XXX de las instrucciones elaboradas para los síndicos de la capital se incluyó la siguiente petición:

Item com moltes vegades los jurats tenint necessitat dels advocats per causes molt necessàries de la ciutat enviant per dits advocats dexen de venir cridats y demanats per los dits jurats que en tal cas los dits jurats y racional puxen imposar penes als dits advocats y executar aquelles les quals penes sien aplicades al Spital General de la ciutat ${ }^{93}$.

Una vez en Cortes, la queja fue elevada por los tres brazos, aceptando el príncipe Felipe que les pudiera sancionar hasta 100 sueldos extraídos de su sueldo,

89. AMV. $M C, \mathrm{~A}-82$, fol. 238v-239. Micer Benavent ejerció como asesor del justicia civil en 1530-1531, 1537-1538 y 1554-1555; asesor del justicia criminal 1541-1542; examinador de notarios 1546-1547 y corregidor de abogados 1549-1550.

90. AMV. $M C, \mathrm{~A}-82$, fol. 258.

91. AMV. $M C, \mathrm{~A}-76$, fols. 524v-525. Micer Mascarell en esa misma juradería participó en la embajada que fue a tierras alemanas con una serie de peticiones relativas a la Real Audiencia, la actividad de los diferentes visitadores reales y defensa.

92. AMV. $M C, \mathrm{~A}-68$, fols. $11 \mathrm{v}-14 \mathrm{v}$.

93. AMV. $M C$, A-75, fols. $64-74 \mathrm{v}$.

(C) Ediciones Universidad de Salamanca / ®@ Stud. his., H. ${ }^{a}$ mod., 38, n. 1 (2016), pp. 319-350 
por cuanto el abandono de sus funciones ralentizaba, e incluso detenía en muchos aspectos, el gobierno de la capital:

Item senyor com la ciutat de Valencia tingué quatre advocats assalariats per a que los jurats de aquella puguen ésser aconsellats en cars que tenen necessitat de consell, hes segueixquen de cascun dia que puix los dits advocats tenen son salari cert, encara que sien requests, e demanats no volen venir a la Sala, per hon los jurats per falta de consell deixen de fer moltes provisions, o les han de diferir en gran dany de la cosa pública. Supliquen per çò los dits tres braços sia mercè de vostra Altesa provehir, e manar, e cometre als dits jurats tostemps que tal culpa, o renitència se trobarà en algú, o alguns advocats puixen mulctar a aquells, e provehir que lo clavari comú de llurs salaris se retingué tant part quanta serà la dita mulcta. Plau a Sa Alteza ab que la mulcta sia fins en cent sous ${ }^{94}$.

De acuerdo con la documentación manejada, esta sanción no se aplicó a pesar de que los abogados de la Ciudad continuaron haciendo cierta dejación de funciones.

A lo largo del periodo analizado, la ciudad de Valencia envió más de medio centenar de embajadas, las más de las veces, a la Corte. En la elaboración de las instrucciones con las que partían los emisarios siempre se contaba con el auxilio de los abogados de la Ciudad, participando también como integrantes en varias de estas legaciones. Destacar sobre todo, en este sentido, la gestión de don Pedro Luis Sanç, que participó en tres delegaciones: en 1531-1532 visitó a la virreina para demandarle saca de trigo y carne; en 1536-1537 acudió ante el rey por un enfrentamiento entre los barqueros del Grau contra Carlos Torrelles que, por privilegio real, había obtenido el monopolio de este trabajo y en la juradería de 1552-1553 volvió a la Corte para resolver otro choque de competencias, en este caso por el nombramiento del escribano de los albaranes. Además de ser pieza clave en los preparativos de las Cortes Generales, los abogados municipales también participaron en ella como síndicos. En las de 1528 actuaron como tales micer Dimas Aguilar y micer Francisco d'Artés ${ }^{95}$; en 1533 repitió micer Aguilar, quien mantuvo un agrio conflicto con los jurados por su propuesta de reducir los censales ${ }^{96}$. A pesar de ello, volvió a ejercer como síndico en las de 1542 junto con micer Cosme

94. García Cárcel, R. (ed.): Cortes del reinado de Carlos I. Valencia, 1972, p. 187.

95. AMV. $M C, \mathrm{~A}-62$, fol. 414.

96. AMV. MC, A-65, fols. 277-279.

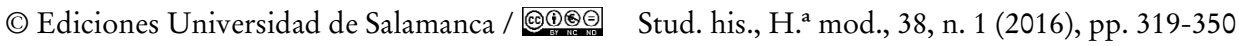


Abat ${ }^{97}$. Micer Francisco Ros fue síndico en las Cortes de $1537^{98}, 1547^{99}$ y $1552^{100}$. Aspectos estos dos últimos que esperamos profundizar en futuras investigaciones.

$$
* * *
$$

Podemos concluir, por tanto, que el cargo de abogado de la ciudad de Valencia continuó siendo vitalicio durante la primera mitad del siglo xvi y que estuvo bajo el control del Consell Secret y del Consell General, tras la injerencia de la Corona durante el reinado del Católico. Muchos de los juristas que lo ejercieron lo simultanearon con su condición de oficiales reales con la consiguiente carga laboral que ello comportaba y que, muchas veces, les llevaba a abandonar sus obligaciones municipales o tener que mantenerse al margen de algún pleito por incompatibilidad. Una de las constantes a lo largo del periodo analizado es la queja de los dirigentes capitalinos de la falta de asesoramiento legal, o bien por dejación de funciones de sus abogados, o bien por el desinterés de otros juristas a trabajar para la Ciudad. Carencia que se intentó paliar no destituyendo a los que ejercían como tales sino nombrando a abogados extraordinarios -con los mismos emolumentos que los ordinarios-, y coadjutores. Fue a partir de la década de los cuarenta cuanto empezó a institucionalizarse la figura del coadjutor del abogado de la Ciudad. La enorme carga laboral, los alifafes de la edad y los servicios prestados al Municipio fueron los argumentos que los abogados de la Ciudad esgrimieron ante el Consell Secret y el Consell General para lograr que se les concediera un auxiliar que, ejerciendo el cargo conjunta o separadamente, no recibiría ningún tipo de remuneración. Petición que fue siempre aceptada, pues además permitía al Municipio tener un mejor asesoramiento sin coste alguno. Los coadjutores normalmente pasaban a tener el cargo en propiedad a la muerte del titular.

97. AMV. $M C, \mathrm{~A} 72$, fols. 21-22.

98. AMV. $M C, \mathrm{~A}-69$.

99. AMV. $P Q, \mathrm{~B}-31$.

100. AMV. $M C, \mathrm{~A}-77$, fols. $563-568 \mathrm{v}$.

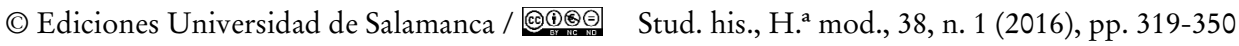


PILAR VALOR MONCHO

LOS ABOGADOS DE LA CIUDAD DE VALENCIA DURANTE EL REINADO DE CARLOS I

\section{BiBLIOGRAFÍA}

Belenguer Cebrià, E.: Fernando el Católico y la ciudad de Valencia. Valencia, 2012.

BERnABÉ GIL, D.: «Los juristas en la burocracia municipal. Asesores y abogados ordinarios de la ciudad de Orihuela en el siglo XVII», en Homenatge al doctor Sebastià García Martínez. Vol. II, Valencia, 1988, pp. 133-147.

CAnet Aparisi, T.: La Magistratura Valenciana (s. XVI-XVII). Valencia, 1990.

Canet Aparisi, T.: «La justicia del emperador. La refundación Carolina de la Audiencia valenciana», en MARTínez Millán, J. (coord.): Carlos V y la quiebra del humanismo político en Europa (1530-1558). Vol. 2, Madrid, 2001, pp. 173-198.

CANET Aparisi, T.: «Entre la visita y la sucesión. La resistencia a la virreinalización administrativa en Valencia entre Carlos V y Felipe II», Estudis, 28, 2002, pp. 205-240.

CANET APARIsI, T.: «La abogacía fiscal: ¿una figura conflictiva en la administración valenciana?», en Narbona, R. (coord.): La Mediterrània de la Corona d'Aragó, segles XIII-XVI. Vol. 1, Valencia, 2004, pp.523-550.

Febrer Romaguera, M.: «Pere Joan de Capdevila, catedrático y abogado (hc. 1495-1558): biografía y estudio bibliográfico de su biblioteca jurídica», en Congreso Universitario de Ciencias de la Documentación. Vol. 1, Madrid, 2000, pp. 197-237.

Felipo OrTs, A.: La Universidad de Valencia en el siglo XVI (1499-1611). Valencia, 1993.

Felipo ORTs, A.: «Las visitas de inspección a la ciudad de Valencia durante el siglo XVI», Studia Historica. Historia Moderna, 25, 2003, pp. 241-267.

Felipo OrTs, A.: La oligarquía municipal de la ciudad de Valencia. De la Germanía a la insaculación. Valencia, 2002.

García Cárcel, R. (ed.): Cortes del reinado de Carlos I. Valencia, 1972.

Graullera SanZ, V.: Los primeros juristas valencianos. Valencia en la Baja Edad Media. s. XIII Y XIV. Valencia, 2000.

Gual Camarena, M.: «Los abogados de la ciudad de Valencia en el siglo xiv. Notas y documentos». VIII Congreso de Historia de la Corona de Aragón, vol. II. Valencia, 1970, pp. 221-240.

JUAN VIDAL, J.: El sistema de gobierno en el reino de Mallorca (siglos XV-XVII). Mallorca, 1996.

LORITE MARTínez, I.: Las deliberaciones del Estamento militar valenciano (1488-1510). Tesis de licenciatura inédita. Valencia, 1999.

Narbona Vizcaíno, R.: «Los Rabassa, una familia patricia de Valencia medieval», Anales de la Universidad de Alicante. Historia medieval, 7, 1988, pp. 111-136.

VAllés Borràs, V.: La Germanía. Valencia 2000.

VAllés Borràs, V.: «Notarios y juristas al servicio de la Germanía», Estudis, 26, 2000, pp. 203-225.

Valor Moncho, P.: «Tres Baronías y un conflicto. La pugna por la Pobla, Paterna y Benaguasil entre el Duque de Segorbe y Ciudad de Valencia (1500-1550)», en FranCH, R.; Andrés, F. y BeníteZ, R. (coords.): Cambios y Resistencias Sociales en la Edad Moderna.: Un análisis comparativo entre el centro y la periferia mediterránea de la Monarquía Hispánica. Valencia, 2014, pp. 141-152.

(C) Ediciones Universidad de Salamanca / ®@ Stud. his., H. ${ }^{a}$ mod., 38, n. 1 (2016), pp. 319-350 
Viciana, M.: Crónica de la inclita y coronada ciudad de Valencia, vol. IV, ed. Sebastián García. Valencia, 1972.

Vidal Beltrán, E.: Valencia en la época de Juan I. Valencia, 1974.

(C) Ediciones Universidad de Salamanca / ®@ Stud. his., H. ${ }^{a}$ mod., 38, n. 1 (2016), pp. 319-350 